\title{
Toxicity of Sanguinaria canadensis L. as Compared to Aloe vera L. against Brine Shrimp (Artemia salina) Using the Probit Methodology
}

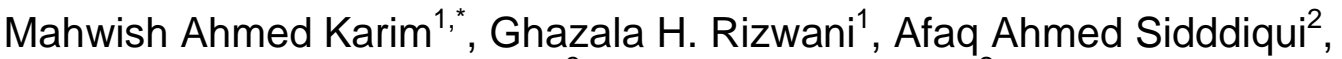 \\ Muhammad Farhanullah Khan ${ }^{3}$ and Mansoor Ahmed ${ }^{2}$ \\ ${ }^{1}$ Department of Pharmacognosy, Faculty of Pharmacy, University of Karachi, 75270, Pakistan \\ ${ }^{2}$ Department of Pharm. Chem., Faculty of Pharmacy, University of Karachi, 75270, Pakistan \\ ${ }^{3}$ Department of Zoology, Faculty of Science, University of Karachi, 75270, Pakistan
}

\begin{abstract}
Toxicity study of Sanguinaria canadensis L. was determined as compared to Aloe vera (L.) Burm. f. against brine shrimp (Artemia salina). Upon statistical analysis of obtained toxicity bioassay data through the method of probits, $\mathrm{LC}_{50}$ of Sanguinaria canadensis was estimated as $0.021 \mathrm{mg} / \mathrm{ml}$, with $(95 \%$ C.I : 0.0091-0.0485) whereas Aloe vera was found to be almost non-toxic showing relatively higher LC $_{50}$ that is, $180783.7 \mathrm{mg} / \mathrm{ml}$.

These results show that Aloe vera that is being used widely as an herbal medicine throughout the world, could be used safely for other various expected purposes for instance IPM etc. where the excessive amount is anticipated to drain into the sea ecosystem ultimately.
\end{abstract}

Keywords: Sanguinaria canadensis L., Aloe vera (L.) Burm. f., invitro toxicity assay, Artemia salina, Probit, LC ${ }_{50}$.

\section{INTRODUCTION}

Sanguinaria canadensis L. (Papaveraceae) is a well known medicinal plant and it is an important part of Homeopathic materia medica for respiratory system ailments. Sanguinarine, an important phytochemical from it, has been shown to posses remarkable antimicrobial activity [1-3]. Likely, Aloe vera (L.) Burm. f. (Liliaceae) is famous for its use in cosmetology as emollient and for burn treatment. For some systemic ailments like constipation its leaf exudates (dried) has been used. Both the plants have reasonable shares in drug market [2, 4-7]. Furthermore, plant materials are being tested for pest management components as well [8].

Toxicity testing of any chemical is carried out when it is expected to get in contact with the living body, skin, mouth, lung or get way inside through ingestion by any mean. The estimation of $L D_{50}$ is the best way of getting an idea of the toxicity profile of any chemical and natural compound [8]. The statistical method for calculating $L D_{50}$ is the method of probits, which was first introduced by Chester Bliss (1932) and developed by Finney (1962). It transforms the sigmoid doseresponse curve to a straight line that can then be analyzed by regression. It is also utilized in bioassays, quantal bioassays and tolerance study [9-12].

*Address correspondence to this author at the Department of Pharmacognosy, Faculty of Pharmacy, University of Karachi, University Road Karachi-75270, Pakistan; E-mail: pharmacognosyp@gmail.com

ISSN: 2223-3806 / E-ISSN: 1927-5951/15
Many of the chemicals are being tested for their possible toxic effects including drugs and medicines [13]. To minimize the associated effects of synthetic chemicals to the man, animals and the environment around the world, inclination is going towards the usage of natural products, instead. Keeping in view this changing trend of world, it is urged to get more knowledge in the field of toxicology of most common plants and their products and thus in this connection Sanguinaria canadensis $L$. was tested as compared to Aloe vera (L.). These tested plants are renowned medicinal plants [1-7], since to screen a wide range of crude plant extracts and cytotoxicity assay using larvae of brine shrimp is a cheap and quick method, therefore presently; the Artemia salina was used as a subject organism.

\section{MATERIALS AND METHODS}

\section{Plant Material and Shrimps}

Plant material and shrimps were reared, collected, processed and/or identified. Hydro-EtOH extract of $S$. canadensis while dried $A$. vera gel was utilized in the study.

\section{Brine Shrimp Lethality Bioassay}

The eggs of brine shrimps (Artemia salina (Leach)) are available in the pet shop as fish food easily. They are stored at $4^{\circ} \mathrm{C}$ and are allowed to hatch in the sea water before the cytotoxic assay. The count of viable larvae after their incubation with the test sample (c) 2015 Lifescience Global 
indicates the $\mathrm{LD}_{50}$ of the respective sample [14]. $50 \mathrm{mg}$ of the brine shrimp eggs were sprinkled in the freshly prepared filtered saline water (38 $\mathrm{g}$ of sea salt $/ \mathrm{L}$ of $\mathrm{D} / \mathrm{W}, \mathrm{pH} 7.4$ also called brine solution) and are allowed to hatch and mature for two days. In the meantime 200 $\mathrm{mg}$ of the extract of plants were weighed accurately to three significant figures and in each, $20 \mathrm{ml}$ of the volatile organic solvent was added. From each of them, then $0.5,5,50,500$ and $5000 \mu \mathrm{l}$ was transferred to five vials to get $1,10,100,1000$ and $10000 \mu \mathrm{g} / \mathrm{ml}$ respectively, of each sample to be tested for the assay after evaporation of the solvent overnight. Other vials were supplemented with control. Then $5 \mathrm{ml}$ of brine solution (sea water) was added and 10 matured larvae were transferred in each vial using Pasteur pipette. The vials were incubated at $25-27^{\circ} \mathrm{C}$, under illumination for 24 hours. After incubation the larvae were observed and dead or alive organism/s were counted and noted down for calculating the $L D_{50}$.

\section{Statistical Analysis}

The experimental data were analyzed using the probit methodology and chi-square test. Probit is a method which transforms a concentration-mortality curve to a straight line which helps in estimating the value of $L_{50}$. Regression equation that was calculated by probit values would be used to measure the concentration that would give percentage mortality as low as zero to as high as hundred percent. Here, the Chi-square test was used to test the relationship between probit mortality and regression mortality [912].

\section{RESULTS}

As given in Tables $\mathbf{1}$ and $\mathbf{3}$, a gradual increase in percent mortality with increase in concentration has been observed. The results were subjected to probit analysis as shown in Tables $\mathbf{2}$ and $\mathbf{4}$ and Graphs $\mathbf{1}$ and 2. The probit mortality equations for $S$. canadensis and A. vera were Mortality $=6.13694+0.6773 \log$ Con . and Mortality $=3.82794+0.2463 \log C o n$. for $\mathrm{LD}_{50} 0.021$ $\mathrm{mg} / \mathrm{ml}$ (95\% C.I : $0.0091-0.0485)$ and $180783.7 \mathrm{mg} / \mathrm{ml}$, respectively. In both the graphs, series 1 denotes that the line was plotted between log concentration and probit values while, series 2 refers that the line was plotted between log concentration and mortality fitted equation.

Table 1: Toxicity of Sanguinaria Canadensis

\begin{tabular}{|c|c|c|c|c|}
\hline Concentration $(\mathbf{m g} / \mathrm{ml})$ & Organisms exposed & Percent Mortality & Probit Value & Mortality=6.13694+0.6773logCon: \\
\hline \hline 0.001 & 30 & 19.1 & 4.1258 & 4.10504 \\
\hline 0.01 & 30 & 39.33 & 4.7285 & 4.78234 \\
\hline 0.1 & 30 & 69.66 & 5.5158 & 5.45964 \\
\hline 1 & 30 & 86.52 & 6.1031 & 6.13694 \\
\hline 10 & 30 & 96.63 & 6.825 & 6.81424 \\
\hline Control & 90 & 1 & - & - \\
\hline
\end{tabular}

Chi- square $=0.999$.

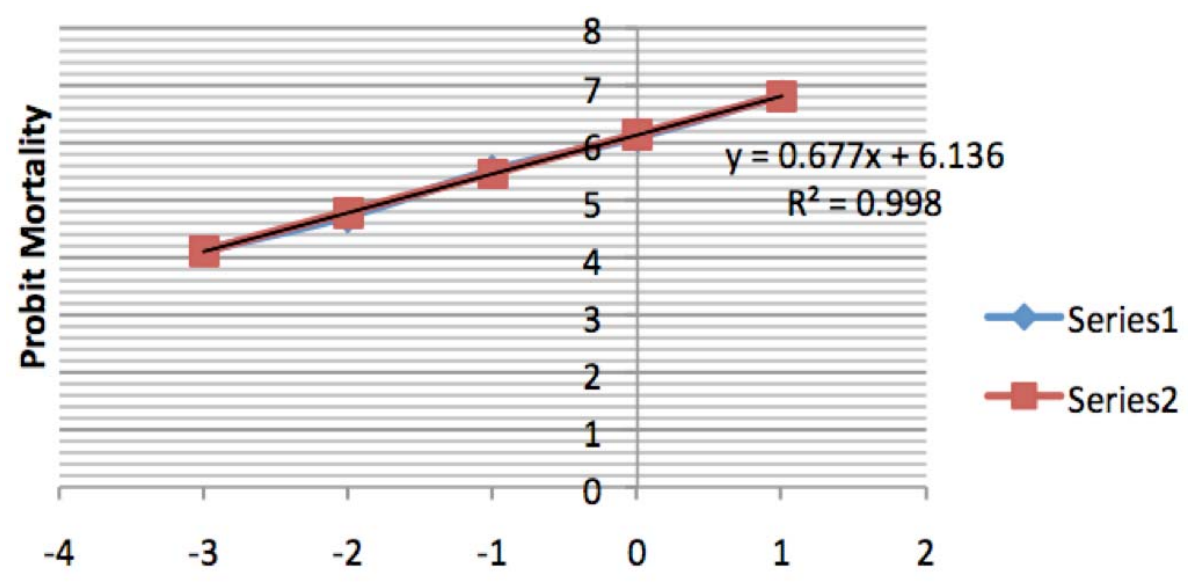

\section{Log Concentration}

Graph 1: Probit mortality curve for Sanguinaria canadensis. 
Table 2: LC of Sanguinaria canadensis

\begin{tabular}{|c|c|c|c|}
\hline Percent mortality & LC $(\mathbf{m g} / \mathbf{m l})$ & S.E. & Dose limit at 95\% C.I. (mg/ml) \\
\hline \hline 10 & 0.0003 & 2.35 & 0.0001 to 0.0015 \\
\hline 30 & 0.0036 & 1.74 & 0.0012 to 0.0106 \\
\hline 50 & 0.021 & 1.53 & 0.0091 to 0.0485 \\
\hline 70 & 0.1229 & 1.56 & 0.0517 to 0.2919 \\
\hline 90 & 1.6216 & 1.97 & 0.4289 to 6.1311 \\
\hline 99 & 57.2859 & 3.14 & 6.0871 to 539.114 \\
\hline
\end{tabular}

Table 3: Toxicity of Aloe vera

\begin{tabular}{|c|c|c|c|c|}
\hline Concentration $(\mathbf{m g} / \mathbf{m l})$ & Organisms exposed & Percent Mortality & Probit Value & Mortality=3.82794+0.2463logCon. \\
\hline \hline 0.001 & 30 & 2.25 & 2.9859 & 3.08904 \\
\hline 0.01 & 30 & 5.62 & 3.4107 & 3.33534 \\
\hline 0.1 & 30 & 8.99 & 3.6592 & 3.58164 \\
\hline 1 & 30 & 12.36 & 3.8593 & 3.82794 \\
\hline 10 & 30 & 15.73 & 3.9931 & 4.07424 \\
\hline Control & 90 & 1 & - & - \\
\hline
\end{tabular}

Chi- square $=0.999$.

Table 4: LC of Aloe vera

\begin{tabular}{|c|c|c|c|}
\hline Percent mortality & LC $(\mathbf{m g} / \mathbf{m l})$ & S.E.* & Dose limit at 95\% C.I. (mg/ml) $^{*}$ \\
\hline \hline 10 & 0.364 & 0.66 & -1.74 to 0.86 \\
\hline 30 & 877.37 & 1.83 & -0.65 to 6.54 \\
\hline 50 & 180783.7 & 2.94 & -0.51 to 11.02 \\
\hline 70 & 37264990 & 4.075 & -0.42 to 15.56 \\
\hline
\end{tabular}

*Values are in logarithm.

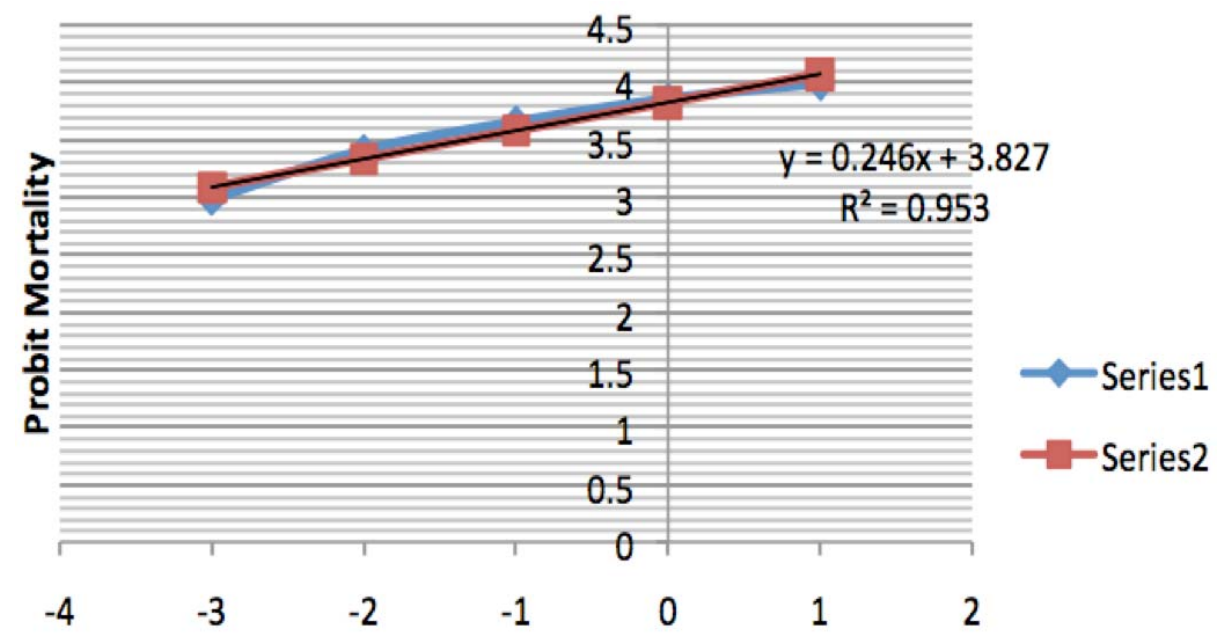

Log Concentration

Graph 2: Probit mortality curve for Alo evera. 


\section{DISCUSSION}

Medicinal plants have been in the life of humans since ages. Now the people are more interesting in getting aware of the possible toxicities of any herbal extract as never before as there had reported such cases of toxicity that ultimately banned the product to be sold. Drug toxicity is a key reason for drug attrition. Identifying potential toxicity at an early stage in drug discovery can save both time and development costs, and reduces the likelihood of late stage failure $[8,14$, $15]$.

Although having potential medicinal value, $S$. canadensis is considered a toxic plant [1-3] and it was also manifested by this research exercise as it showed very low value of $L D_{50}$ in contrast to the edible $A$. vera. The results of this study were in line with another attempt by Jancula Daniel et al., 2007 in which aqueous extract of root of Sanguinaria canadensis showed significant toxicity against aquatic organisms [16]. Although, considered almost non-toxic, Cock and Sirdaarta, 2011, evaluated $A$. vera toxicity on Artemia napulii, and they concluded that the gel of the plant may contain some cytotoxic material and it may manifest toxicity in the concentration as low as $4.3 \%$ with $24 \mathrm{~h} \mathrm{LC} 50$ of $4.6 \% \pm 0.3$ [17].

There are methods that can assess the toxicity profile of any chemical agent and that can test the possible cytotoxic, mutagenic, tumorogenic or cancerogenic potential of it but the cost, efficient handling, high laboratory demands might be the hindrance. The estimation of $\mathrm{LC}_{50}$ using such small animals like brine shrimps are the quick process to get an overview of the nature of the substance tested. Nevertheless, plant materials are being tested for pest management components as well. These results show that Aleo vera could be used safely for the various expected purposes including IPM etc. where the excessive amount is anticipated to drain into the sea ecosystem ultimately [8].

\section{REFERENCES}

[1] Lockie A, Geddes N. Natural health, complete guide to Homeopathy. Dorling Kindersley Ltd. Great Britin 2000; 142, 143.

[2] Plant encyclopedia at: http://www.bioforceusa.com/pflantencyclopaedia/sanguinaria_canadensis.php, Accessed on April $23^{\text {rd }} 2012$.

[3] Godowski KC. Antimicrobial action of sanguinarine. J Clin Dent 1989; 1(4): 96-101.

[4] Reynolds T, Dweck AC. Aloe vera leaf gel, a review update. J Ethnopharmacol 1999; 68: 3-37. http://dx.doi.org/10.1016/S0378-8741(99)00085-9

[5] Shinwari ZK, Rehman M, Watanabe T, Yoshikawa T. A Pictorial guide to medicinal plants of Pakistan 2006. Kohat University of Science and Technology, Kohat, Pakistan: 34.

[6] WHO Monograpgh on selected medicinal plants. WHO press, Geneva 2007; Vol. 3: pp. 194-195.

[7] WOI: The wealth of India. Raw materials. A. Revised edition. India. NISCAIR Press 2003; Vol-1: p. 193.

[8] Rana H. Toxicological studies of Azadirachtaindica and Annonasquamosa extracts in comparision with cypermethrin and endosulfan: comparative toxicological studies of selected plant extracts and insecticides against dipterous flies. PhD thesis submitted to the University of Karachi, Pakistan 2014.

[9] Bliss Cl. The Method of Probits. Science 1934; 79(2037): 3839.

http://dx.doi.org/10.1126/science.79.2037.38

[10] Bliss Cl. The Calculation of the Dosage-Mortality Curve. Ann Appl Biol 1935; 22(1): 134-167. http://dx.doi.org/10.1111/j.1744-7348.1935.tb07713.x

[11] Finney DJ. Probit Analysis, $3^{\text {rd }}$ edition. Cambridge University Press 1971.

[12] Finney DJ, Stevens WL. A Table for the Calculation of Working Probits and Weights in Probit Analysis. Biometrika 1948; 35(1/2): 191-201.

http://dx.doi.org/10.2307/2332639

[13] Deora PS, Mishra CK, Paresh M, Rani A, Shrivastava B, Nema RK. Effective alternative methods of LD50 help to save number of experimental animals. J Chem Pharm Res 2010; 2(6): 450-453.

[14] Meyer BN, Ferrigni NR, Putnam JE, Jacobsen LB, Nichols $\mathrm{DE}$, McLaughlin JL. Brine shrimp: A Convenient general bioassay for active plant constituents. Plantamedica 1982; 45: 31-34. http://dx.doi.org/10.1055/s-2007-971236

[15] Moulds RFW, Malani J. Kava: herbal panacea or liver poison? Med J Aust 2003; 178(9): 451-453.

[16] Jancula D, Suchomelova J, Gregor J, Smutna M, Marsalek B, Taborska E. Effects of aqueous extracts from five species of the family Papaveraceae on selected aquatic organisms. Environ Toxicol 2007; 22(5): 480-6. http://dx.doi.org/10.1002/tox.20290

[17] Cock IE, Sirdaarta J. The toxicity of Aloe barbadensis Miller juice is due to the induction of oxidative stress. Adv Environ Biol 2011; 5(2): 288-299.

\section{DOI: http://dx.doi.org/10.6000/1927-5951.2015.05.01.1}

(c) 2015 Karim et al.; Licensee Lifescience Global.

This is an open access article licensed under the terms of the Creative Commons Attribution Non-Commercial License (http://creativecommons.org/licenses/by-nc/3.0/) which permits unrestricted, non-commercial use, distribution and reproduction in any medium, provided the work is properly cited. 